\title{
Effectiveness of Online Advertising in India
}

\author{
S. Anbumalar, C. Vignesh, V.S. Dharani, M. Abarna
}

\begin{abstract}
With the rapid growth in the IT Industry, many companies have started using the internet as primary source of advertising platform for taking advantage of online technologies. The Internet has became more familiar as online marketers found that Internet provides more convenience and command over the advertising area. The primary objective of this research is to find out how efficiently does the online advertising performs its role in making sale of goods to the customers with attractive offers and discounts to retain such online customers for a long time. Online Advertising became the primary source platform for promoting new products using advanced Internet features. With the birth of Internet, business world became more customized and many people started to buy their products online that could make their work easier and more faster. Online Advertising gives a creative dimension and unique characteristics to the product which is an added advantage. This gives a great progress in online business which reaches the ultimate aim of the marketer. Online Advertising viewers has no restrictions as it can be viewed 24/7 across the globe. By dealing with online market, marketers can reduce the transaction cost as it can contribute for the earnings of the company and also it is very secured while competing against International Marketing. In this Research, we would discuss about the origin and history of Online Advertising, Characteristics and Forms of Online Advertising, What are the challenges that marketers are facing while doing Online Advertising, Recent Trends in Online Advertising and Search Engine Optimization Statistics.
\end{abstract}

Key Words: Internet, Optimization, International Marketing Websites: www.google.com, www.sodhganga.com

\section{INTRODUCTION}

Online Advertising is a form of marketing which uses the online platforms to promote the products. It helps businesses in targeting global customers. In Common parlance the products or services which are being offered is very cost effective and it is also a benefit to the customers. Through Online Advertising people can expect more returns of their investments.

\section{ORIGIN OF ADVERTISING}

The Origin of Advertising arises from the period of Indus Valley Civilization. Major Streets of Mohenjo-Daro found people walking with drums to bring the attention of everyone who are present on the streets to deliver some messages.

Major cities of Harappa used some signs to make people buy art and craft products which are being sold.

During the period of Emperor Asoka, many stones and pillars were used as a source of public announcement.

Revised Manuscript Received on September 14, 2019.

Dr. S. Anbumalar, Professor and Head- Department of Commerce Sri Krishna Arts and Science College, Coimbatore,Tamil Nadu, India.

C. Vignesh, Student- M.Com- Final YearSri Krishna Arts and Science College, Coimbatore, Tamil Nadu, India.

V.S. Dharani , Student- M.Com- Final YearSri Krishna Arts and Science College, Coimbatore, Tamil Nadu, India.

M. Abarna, , Student- M.Com- Final YearSri Krishna Arts and Science College, Coimbatore, Tamil Nadu, India.
In Olden days, the cities like Greece and Rome used drummers and signs to deliver messages to people about the products that are being sold in the market.

Egyptians used papyrus paper to convey messages to people.

In some parts of Asia, Africa and South America wall paintings and rocks were used for conveying the messages to people.

\section{HISTORY OF ADVERTISING IN INDIA}

"Bengal Gazette" was the first news paper of Indian sub continent by "The Calcutta General Advertisers". It was started on $29^{\text {th }}$ January 1780 .

By 1830's, the number of newspapers in India got expanded to three times. These newspapers and periodicals were now published on regular basis in India.

In 1905, B. Dattaram \& Co. was the oldest Advertising Agency in India.

In 1909, Calcutta Advertising Agency was launched.

By 1920's India had some Advertising Agencies which were operating in major cities. Few of these advertising agencies were Modern Publicity service in Bombay \& Calcutta and Oriental Advertising Agency in Trichy.

During the period 1920-22, Swadeshi Movement in India also helped in growth of advertising industries as a whole.

In 1931, The National Advertising Agency has emerged as the first full-fledged Advertising Agency.

In 1936, Indian Broadcasting company called All India Radio (AIR) has been launched.

In 1951, the Indian Society of Advertisers was formed which was followed by the formation of society of Advertising Practitioners in may 1958.

In 1978, the first television commercial form of advertisement was launched.

In 1990, Internet has been started using for promoting Online Advertisement.

In 1991- the first India targeted satellite channel named ZEE TV started its broadcast.

\section{REVIEW OF LITERATURE}

Thamaraiselvan Natarajan (2013) investigated the students belief towards social media advertising. Seven factors viz. Pleasure, Product, Information, Social Image, Good for economy, Materialism, Falsity and Value corruption was considered for the research. The study revealed that working people showed a negative attitude towards falsity of advertisements while a high positive attitude was shown towards the social role and good for the economy. Both students and working professionals have opinion that advertisements are materialistic and have value 
corruption. The study suggested that advertisement should be designed with a consciousness of the society.

Ali Bassam Mahmood(2012) investigated the difference in beliefs and attitude among Indian Male and Female towards online advertising. The findings revealed that male respondents shows information, entertainment, the social role, falsity and value corruption. It is suggested that more feminine features could be added in the advertisement to enhance positive belief and attitude among women viewers.

\section{ESSENTIALITIES OF ONLINE ADVERTISING}

Online Advertising has became the vital factor for the success of an Online Business. There are some essentialities of Online Advertising which are discussed below:

\section{Global Reach}

Through Online Advertising marketers can highlight their business beyond their local area to reach the audience at global level. They don't need to travel anywhere to expand their business, as they can easily connect with their audience through Internet.

\section{Focusing Potential Customers}

Through Online Advertising, Ads can be posted to the selected group of customers who are in plan to buy such products.

\section{Fast and Easy}

As compared to Traditional Advertising, Online Advertising has become more easier and faster in today's competitive world. It is also advantageous that Online Advertising consumes only short span of time to reach the audience whereas Traditional Advertising involves lengthy procedures and consumes more time to reach out the audience.

\section{FORMS OF ONLINE ADVERTISING \& RESULTS}

Marketers may adopt different strategies that are to be used in Online Advertising in an efficient manner to attract the targeted audience by making them to come forward to buy the product through online platform. There are some main forms of Online Advertising that are discussed below:

\section{Display Advertising}

These are the original forms of Online Advertising which appears on the third party websites. Examples of Display Ads are floating banners, pop-up ads etc...

\section{Remarketing}

It is one of the modern form which marketers uses to remarket the product with new features that the customer already purchased from them, It is mainly done to retain the customers for a long time.

\section{Video Ads}

It is also the most used form of advertising that are made to grab the customers soon after viewing the ads in the form of video. The content in the video will be in the attractive manner, so that it could attrct the customer's attention very faster. Educational Video Ads are made to cover the students and Business Plan Videos are made to attract the Business People as a whole.

\section{CHALLENGES OF ONLINE ADVERTISING}

In spite of some benefits that online marketers enjoys, there are some challenges that makes the online advertisers to satisfy their competence, they are as follows:

\section{Rapid Growth}

The Digital era of Online Advertising is in development stage. More number of websites are being introduced every day. The decision regarding where to advertise is the questionable situation that arises in the minds of Advertisers.

\section{Ad Blockers}

In today's scenario, Ad Blockers are costing Advertisers billion of dollars. The software is the only reason for the cause of rejection of many Ads that could spread Malwares or Spywares to the consumer's system.

\section{Increasing Cost}

Brands are the only cause that leads to increase the cost of digital advertisement. International Brands which needs to go for online advertisement incurs huge cost whereas Domestic Brands which needs to go for online advertisement incurs low cost. This creates Brand Discrimination in the minds of marketers.

\section{Advertising Duplicate Product}

Nowadays, advertising duplicate products became the challenging factors in online websites. People who are literate can able to predict whether the advertised product is original or duplicate but the people who are illiterate cannot find whether the product advertised is original or duplicate which affects them as a whole.

\section{RECENT TRENDS IN ONLINE ADVERTISING}

Due to Technological Advancements Online Advertising Reached the Peak of the Market in recent times. Some of the trends are listed below:

\section{Voice Search}

Voice Search is the developing trends in a faster basis. It will be voice based according to the comscore features. Top brands are in discussion that how to deliver their promises through voice enabled system as it is more affordable and offer more facilities than ever before while large number of customers are using voice search to interact with their brands. Some examples are Google Assistant, Amazon's Alexa , Apple Homepod, etc...

\section{Smarter Chat}

Chat bots are being introduced in recent years. Majority of users use chat bots as the customer service communication system . It plays a vital role in improving the customer experience and help the marketers to assist the

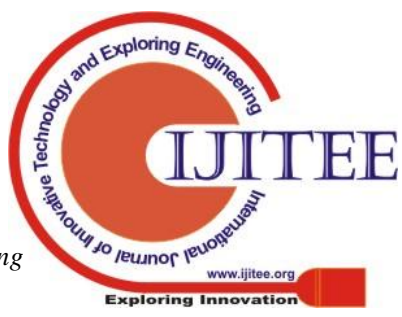


customers as and when needed.

\section{Augmented and Virtual Reality Marketing}

It is one of the major applications that are used by some marketers. It brings some real experience that customers could see the product's feature lively and it will attract those customers who wants to test the product through online itself. Michael Kors is a successful example for augmented reality ads . It is an created ad in facebook which helps the customers to try and buy their sunglasses.

\section{AI and Machine Learning}

AI allows marketers to predict future patterns of their customers based on the obtained informations. With this information, marketers can plan for how to retain the active customers through different channels like direct mail, sales outreach, etc..

Some of the major Online Advertising companies in India are

\section{- Group M}

- $\quad$ Law and Kenneth Saatchi and Saatchi Pvt. Ltd.

- JWT

- $\quad$ Madison Cann Erickson India Pvt. Ltd.

- $\quad$ Ogilvy and Mather Pvt. Ltd.

\section{CONCLUSION}

Online Advertising has grown up very rapidly over past decade as more number of customers switched over from Traditional Purchasing to Online Purchasing. This growth will continue for another decades also. The main reason for growth in Online Advertising is that many offline advertisers feel that consumers are changing often as well as their attitude. In future Online Advertising will become the only platform to reach huge volume of consumers worldwide. In recent times due to technological advancements major companies like Amazon, Google, etc.., designed new strategy for development of Online Advertisement. In Upcoming years Online Advertising will become the primary source for every marketers to promote their products.

\section{REFERENCES}

1. Belch, George E and Michael A. Belch (2001). "Online Advertising and Promotion". New York Mc Graw -Hill/ Irwin.

2. Dahlen, Michael (2001). "Banner Advertisement through a New Lens". Journal of Advertising Research, Volume 41, Number 4. PP. 23-30.

3. Ducoffe, R.H (1996). "Advertising Value and Advertising on the Web". Journal of Advertising Research. Vol-36, Issue 5, PP 21-35. 